\title{
Information Literacy Level of Students of Universitas Negeri Padang Using the Big 6 Model
}

\author{
Marlini $^{1(*)}$, Elva Rahmah ${ }^{1}$ \\ ${ }^{1}$ Universitas Negeri Padang, Indonesia \\ *Corresponding author.Email: marlini@fbs.unp.ac.id
}

\begin{abstract}
This research discusses the level of information literacy of student of Universitas Negeri Padang using The Big 6 Model. This research uses explanative method which aimed to explain why events occur, and to build and develop theories or concepts. The data obtained by directly distributing questionnaires. Data analysis is conducted to answer the research problem. The data collected was simplified, processed then presented by calculating the student information literacy level score. The data was processed in tabular form so it's easy to read and present. The interpretation done to look for broader meanings and implications of the data displayed. The data that has been calculated and grouped in a table was presented descriptively into statement sentences that describe the data clearly. The Researchers found that the level of student information literacy is in low level, the student's knowledge about information literacy activities is still not good. Many students still do not understand the ethics and stages to find information. These problems cause the students of being wrong in obtaining and using information. In addition, in the evaluation activities there are not many students sort the level of usefulness of information needed, students only search for information and take the information without reading and understanding it in advance before using it. So, the results obtained can be concluded that students still do not understand the actual information literacy ability and students are still classified as students with low information literacy skills.
\end{abstract}

\section{Keywords: Information literacy, information}

\section{INTRODUCTION}

In today's generation, literacy is more than just writing, but it includes thinking skills using knowledge sources in print, visual, digital and auditory forms. This ability is called information circulation. However, there is a growing recognition that information literacy in the learning process needs to be changed in order to ensure that they are relevant to the present / present generation.

Universitas Negeri Padang (UNP) in developing 21st century skills including collaboration, communication, ICT (or digital) literacy, creativity, critical thinking and problem solving, introducing innovative and studentcentered technologies and encouragement of collaboration and group work, together developing the role of the lecturer as a guide or mentor.

According to Sitti (2014), Rahmania (2015), Azim (2016), Hendra (2016), Yudistira (2017), Veri (2017) Azim (2016), information is a collection of facts that have been processed into a form of data, so that it can be more useful and can be used by anyone who needs these data as knowledge or can be used in decision making.

Harsiati (2018), Erika (2017), Arief (2016), Yudistira (2017), Amiq (2018), Aulia (2017), Diah (2016), Komariah (2018), Hidayat (2018), Nurul (2018), Yudistira
(2017), there are four information literacy models, namely the Big 6, The seven Pilars of Information Literacy, The Empowering 8 and The seven Faces of Information Literacy models. One model of information literacy that is widely used in schools, higher education institutions and companies. This model bases identification in six steps namely: defining tasks, information retrieval strategies, location and access, use of information, doing synthesis, and evaluating.

\section{METHOD}

This type of research is explanative. Explanative research is research that aims to explain why events occur and to build and develop theories or concepts because if researchers want to explain the causal relationships between variables through testing hypotheses, then the research is no longer called descriptive research but hypothetical testing research or explanation research.

The approach taken in this research is to identify models and elements of student technology, media and information literacy. Then analyze the model and information literacy elements with reference to the model and information literacy elements that have been applied by students. In this study, the authors describe the data 
obtained from respondents (in this case students) through a questionnaire questionnaire to be further formulated and interpreted. Before describing, the authors distributed questionnaires containing questionnaires and a checklist. Questions from this questionnaire relate to three things, namely technology literacy, media and information. Each with four answer categories, strongly agree $=1, \mathrm{~b}$. agree $=$ 2 , c. Disagree $=3$, and d. Strongly disagree $=4$. Four scales were used in this study with the reason to facilitate respondents. The population in this study were students of the Padang State University GPA Study Program students who entered the 2016-2018 academic year. The sample used is a random sample with the assumption that the population has the same background and traits.

\section{RESULTS AND DISCUSSION}

This study aims to look at: (1) the level of technological literacy of students; (2) get a picture of how the level of student media literacy is; (3) knowing how the level of information literacy is students and (4) knowing the relationship between technology literacy, media, and information literacy in students. Based on research conducted on 429 respondents, the results can be seen as follows:

Literacy of Technology.

Based on the explanation in Table 14 above the average score of technological literacy is 2.59 with a level of achievement of $64.70 \%$ which is in the sufficient category. The highest respondent's achievement is in statement number 1: "You understand what technology is. "It means that on the whole, the average respondent has understood technology with a level of achievement of $82.23 \%$. While the lowest respondent's achievement is in statement number 17 namely "understanding the process of mass media content production" Means that in this statement most respondents do not understand production in mass media, then statement number 18 and 19 namely "able to make mass media message content and understand the rules of making message in mass media "with a level of achievement of $49.59 \%$, for more details can be seen in the following histogram:

Media Literacy

Based on the explanation in Table 2 above the average score of media literacy is 2.88 with an achievement level of $71.96 \%$ which is in the good category. The highest respondent's achievement is in statement number 25 , which is "understanding what print media is." Meaning that most respondents understand print media because they are very familiar among respondents. While the lowest respondent's achievement is in statement number 36 which is "You are not able to analyze the truth of the contents of the mass media." Meaning that in this case the respondent might be able to analyze the truth of the mass media because the respondents are intellectuals.

Information Literacy

Based on the explanation in Table 3 above, the total average score of the Information Literacy variable is 2.61 with an achievement level of $65.17 \%$. The highest respondent's achievement is in statement number 57 which is "You understand when to use the information obtained." Means that most respondents can use information wisely, whenever and wherever. While the lowest respondent's achievement is in statement number 48 namely "You are not able to know the information needs for yourself." The respondent's achievement rate is $48.8 \%$, this means that there are a small number of respondents who do not need information contrary to the results most of the respondents stated as one of the needs, especially with easy access today.

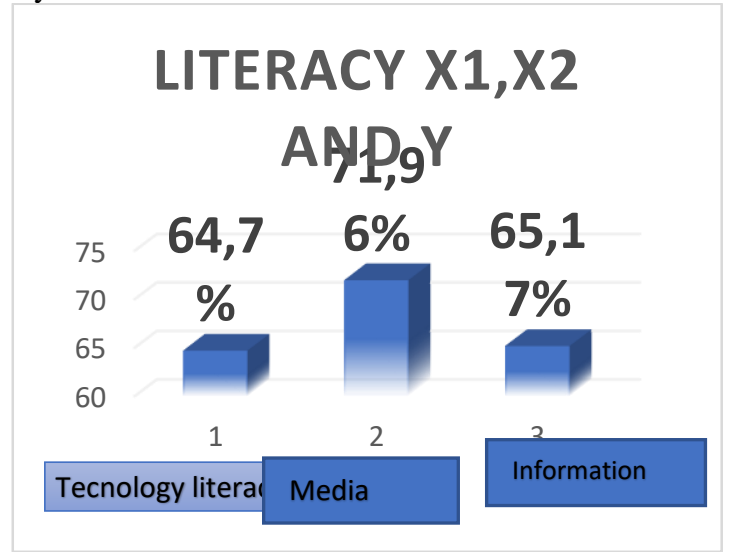

Figure 1. Research Variables

The Relationship between Technology Literacy and Media Literacy with information literacy

The relationship between technology literacy and media literacy with information literacy shows a constant of 8.028 indicating that there are no independent variables, namely technological literacy and media literacy, information literacy. positive at 8.028. Technology literacy variable, has a positive regression coefficient of 0.152 . Thus information literacy will increase by 0.152 units, if technological literacy increases by one unit. Media literacy variable, has a positive regression coefficient of 0.229 Thus information literacy will increase by 0,229 units, if media literacy increases by one unit. From the description above it can be concluded that the more effective model used for students and students is the Big 6 model because this model is more flexible than other information literacy models, this model can be applied to almost all human problems related to decision making which uses information as a basis for decision making.

\section{CONCLUSION}

Based on the previous description, it can be concluded as follows. The ability of information literacy of students of Padang State University is still low and the ability of technology literacy is also low but the media literacy of students is quite high compared to information literacy and technological literacy, because in the information literacy activities UNP students often abuse media use in finding information carried out by students. students use smartphones in search of information but there are still many students who use smartphones as a medium for entertainment. Student knowledge about information literacy activities is still not good. many students still do 
not understand ethics and the stages in finding good and correct information. This often results in students being wrong in getting and using information. In addition, in the evaluation activities there are not many students who rank the level of usefulness of the information they need, students just simply search for information and get it without reading and understanding in advance the information to be used.

\section{REFERENCES}

[1] Amiq, Fahmi dkk. (2018). Pelatihan Dan Pemanfaatan Literasi Informasi E-Wakaf Untuk Pengelolaan Administrasi Wakaf Sebagai Dukungan Layanan Prima Pejabat Pembuat Akta Ikrar Wakaf. Jurnal Abdimasku, Vol. 1, No. 2, hlm 55-62.

[2] Arief, Wicaksono. (2016). Profil Literasi Informasi Pustakawan Indonesia. Jurnal Berkala Ilmu Perpustakaan dan Informasi, Vol. XII, No. 1, hlm 1-9.

[3] Arikunto. (2010). Prosedur Penelitian: Suatu Pendekatan Praktek. Jakarta: Rineka Cipta.

[4] Arista, Mahaseptiviana. (2014). Analisis Dan Perancangan Sistem Informasi Penjualan Air Minum Pada CV Air Putih. Jurnal Sistem Informasi, Vol. 3, No.2, hlm 1-6.

[5] Aulia, Akbar. (2017). Membudayakan Literasi Dengan Program 6M di Sekolah Dasar. Jurnal JPSD, Vol. 3, No. 1, hlm 42-52.

[6] Azim, Ramadhan dkk. (2016). Siaset Fakultas Teknik Universitas Halu Oleo Dengan Menggunakan Sistem Penunjang Keputusan Metode Weighted Product Dan Sistem Informasi Geografis Berbasis Web. Jurnal Semantik, Vol. 2, No. 2, hlm 65-74.

[7] Azim, Ramadhan dkk. (2016). Siaset Fakultas Teknik Universitas Halu Oleo Dengan Menggunakan Sistem Penunjang Keputusan Metode Weighted Product Dan Sistem Informasi Geografis Berbasis Web. Jurnal Semantik, Vol. 2, No. 2, hlm 65-74.

[8] Bayu, Firmansyah. (2017). Kompetensi Literasi Mahasiswa Dalam Pembelajaran Mata Kuliah Seminar Di Prodi Bahasa Dan Sastra Indonesia. Jurnal Ilmiah Edukasi\&Sosial, Vol. 8, No. 1, hlm 12-17.

[9] Dewi, Nirmala Sari. (2018). Implementasi Gerakan Literasi Sekolah Bagi Siswa Tunarungu Di SDLB-B Karya Mulia 1 Surabaya. Jurnal Pendidikan Khusus, Vol. 1, No. 1, hlm 1-20.

[10]Dewi, Nirmala Sari. (2018). Implementasi Gerakan Literasi Sekolah Bagi Siswa Tunarungu Di SDLB-B Karya Mulia 1 Surabaya. Jurnal Pendidikan Khusus, Vol. 1, No. 1, hlm 1-20.

[11] Diah, Sri Rejeki dkk. (2016). Literasi Informasi Motivasi Berwirausaha Ibu Rumah Tangga Kelurahan Nagasari Kabupaten Karawang Barat.
Jurnal Kajian Informasi\&Perpustakaan, Vol. 4, No. 2, hlm 149-160.

[12] Ekkal, Prasetyo. (2015). Rancang Bangun Sistem Informasi Sekolah Tinggi Ilmu Ekonomi Rahmanyah Kabupaten Musi Banyuasin Berbasis Website. Jurnal Informanika, Vol. 1, No. 2, hlm 19-30.

[13]Erika, Fahd Arsyadi dkk. (2017). Studi Komparatif Kemampuan Literasi Informasi Siswa IPA Dan IPS Di SMA Negeri 1 Semarang. Jurnal Ilmu Perpustakaan, Vol. 6, No. 1, hlm 1-12.

[14]Hendra, Wicaksono dkk. (2016). Analisis Keterampilan Literasi Informasi Pustakawan Pusat Informasi Ilmiah Di Lingkungan Universitas Jenderal Soedirman Purwokerto Berdasarkan Model The Big 6. Jurnal Lentera Pustaka, Vol. 2, No. 1, hlm 21-44.

[15] Iskandar. (2016). Literasi Informasi: Prespektif Pustakawan. Jurnal Jupiter, Vol. XV, No. 1, hlm 10-15.

[16] Ketut, Agustini dkk. (2017). Analisis Pemanfaatan E-Learning Sebagai Knowledge Management Dalam Mendukung Proses Pembelajaran Di Jurusan Pendidikan Teknik Informatika Undiksha. Jurnal Karmapati, Vol. 6, No 1, hlm hlm 1-10.

[17] Koko, Murti Wibowo dkk. (2015). Sistem Informasi Geografis (SIG) Menentukan Lokasi Pertambangan Batu Bara Di Provinsi Bengkulu Berbasis Website. Jurnal Media Infotama, Vol. 11, No. 1, hlm 51-60.

[18] Komariah, N, Prijana. (2018). Upaya Pemberdayaan Perempuan Melalui Literasi Informasi Kesehatan Pada Ibu-Ibu Kader Pkk. Jurnal Aplikasi Ipteks untuk Masyarakat, Vol. 7, No. 1, hlm 26-31

[19] Laila, Hadri Nasution. (2015). Analisis Literasi Informasi Pengguna Perpustakaan Universitas Sumatera Utara. Pustaha: Jurnal Studi Perpustakaan dan Informasi, Vol. 11, No.1, hlm 16-26.

[20] Made, Ngurah Suragangga. (2017). Mendidik Lewat Literasi Untuk Pendidikan Berkualitas. Jurnal Penjaminan Mutu, Vol. 3, No. 2, hlm 154163.

[21]Murti, Diah Pracista dkk. (2018). Hubungan Antara Kemampuan Literasi Informasi dengan Prestasi Belajar Siswa Sman 1 Cibining Kabupaten Bogor. Jurnal Kajian Perpusakaan dan Informasi, Vol. 2, No. 1, hlm 1-5.

[22] Nurul, Hayati. (2018). Perilaku Pencarian Informasi Pemustaka Dinas Perpustakaan dan Arsip Kabupaten Tanggerang (Berdasarkan Model Literasi Informasi Seven Pillars), Buletin Al-Turas, Vol. XXIV, No. 1.

[23] Rahmania, Abidin. (2015). Pustakawan Sekolah Dan Literasi Informasi: Menjawab Tantangan 
Globalisasi. Jurnal Mediasi, Vol. 9, No. 2, hlm 101-120.

[24] Roslina dkk. (2018). Pembelajaran Pemecahan Masalah Pada Materi Bangun Datar Pada Siswa SD. Jurnal Serambi Ilmu, Vol. 19, No. 1, hlm 3556.

[25] Siti, Anggriani. (2016). Budaya Literasi Dalam Komunikasi. Jurnal Wacana, Vol. XV, No. 3, hlm 181-279.

[26] Sitti, Husaebah Pattah. (2014). Literasi Informasi: Peningkatan Kompetensi Informadi dalam proses pembelajaran. Jurnal Ilmu Perpustakaan \& Kearsipan Khazanah Al-Hikmah, Vol.2 No.2, hlm. 117-128.

[27] Sitti, Husaebah Pattah. (2014). Literasi Informasi: Peningkatan Kompetensi Informadi dalam proses pembelajaran. Jurnal Ilmu Perpustakaan \& Kearsipan Khazanah Al-Hikmah, Vol.2 No.2, hlm. 117-128.

[28] Suherli, Kusmana. (2017). Pengembangan Literasi Dalam Kurikulum Pendidikan Dasar Dan Menengah. Jurnal Pendidikan, Kebahasaan, dan Kesusastraan Indonesia, Vol. 1, No. 1, hlm 140150.

[29] Titik, Harsiati. (2018). Karakteristik Tes Literasi Membaca Pada Programme For International Student Asessment (Pisa). Bibliotika: Jurnal Kajian Perpustakaan dan Informasi, Vol. 1(2), No. 1 , hlm 11.

[30] Todd, R.J. 1995. Integrated information skills instruction: Does it make a difference? School Library Media Quarterly, Vol. 23, no. 3: 177-84. www.sconul.ac.uk/sites/default/files/documents/co remodel.pdf [Accessed: 10 May 2017].

[31] Veri, Setiawan. (2017). Strategi Komunikasi Pustakawan Dalam Implementasi Literasi Informasi (Studi Kasus Di Perguruan Tinggi Dengan Menggunakan Dan Memanfaatkan EResources). Jurnal Penelitian Komunikasi dan Opini Publik, Vol. 21, No. 1, hlm 15-29.

[32] Yudistira. (2017). Literasi Informasi Pustakawan Di Perpustakaan Fakultas Teknik UGM Menggunakan Pengembangan Model The Big6. Jurnal Berkala Ilmu Perpustakaan dan Informasi, Vol. 13, No.1, hlm 97-106.

[33] Yudistira. (2017). Literasi Informasi Pustakawan Di Perpustakaan Fakultas Teknik UGM Menggunakan Pengembangan Model The Big6. Jurnal Berkala Ilmu Perpustakaan dan Informasi, Vol. 13, No.1, hlm 97-106.

[34]Zulaikha, Sri Rohyanti. (2015). Mengembangkan Model Perpustakaan Madrasah Dalam Penerapan Literasi Informasi Untuk Mempersiapkan Belajar Sepanjang Hayat. Jurnal Pembangunan Pendidikan: Fondasi dan Aplikasi, Vol. 3, No. 2, hlm 214-224. 